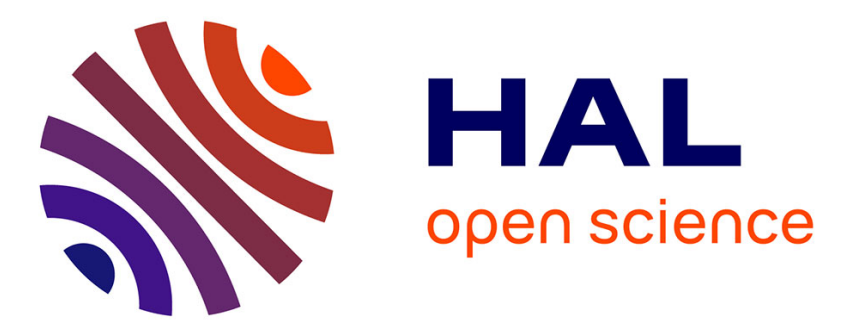

\title{
Hartsfield holoprosencephaly-ectrodactyly syndrome in five male patients: further delineation and review.
}

Catheline Vilain, Geert Mortier, Guy van Vliet, Christèle Dubourg, Claudine Heinrichs, Deephti de Silva, Alain Verloes, Clarisse Baumann

\section{To cite this version:}

Catheline Vilain, Geert Mortier, Guy van Vliet, Christèle Dubourg, Claudine Heinrichs, et al.. Hartsfield holoprosencephaly-ectrodactyly syndrome in five male patients: further delineation and review.. American Journal of Medical Genetics Part A, 2009, 149A (7), pp.1476-81. 10.1002/ajmg.a.32678 . inserm-00405633

\section{HAL Id: inserm-00405633 https://www.hal.inserm.fr/inserm-00405633}

Submitted on 17 Nov 2011

HAL is a multi-disciplinary open access archive for the deposit and dissemination of scientific research documents, whether they are published or not. The documents may come from teaching and research institutions in France or abroad, or from public or private research centers.
L'archive ouverte pluridisciplinaire HAL, est destinée au dépôt et à la diffusion de documents scientifiques de niveau recherche, publiés ou non, émanant des établissements d'enseignement et de recherche français ou étrangers, des laboratoires publics ou privés. 
AJMA 08-0422.R1

\section{Hartsfield Holoprosencephaly-Ectrodactyly Syndrome in Five Male Patients: Further Delineation and Review}

Catheline Vilain ${ }^{1}$, Geert Mortier ${ }^{2}$, Guy Van Vliet ${ }^{3}$, Christèle Dubourg ${ }^{4}$, Claudine Heinrichs ${ }^{5}$, Deephti de Silva ${ }^{6}$, Alain Verloes ${ }^{7}$, Clarisse Baumann ${ }^{7}$.

${ }^{1}$ Service de Génétique Médicale. ULB. Hôpital Erasme. Brussels. Belgium. ${ }^{2}$ Department of Medical Genetics, Ghent University Hospital, Ghent, Belgium. ${ }^{3}$ Service d'Endocrinologie Hôpital Sainte-Justine Université de Montréal. Montréal. Québec. Canada. ${ }^{4}$ Département de Biochimie et Génétique Moléculaire. Centre Hospitalier Universitaire de Rennes. Rennes. France. ${ }^{5}$ Service de Pédiatrie. ULB. Hôpital des Enfants Reine Fabiola. Brussels. Belgium. ${ }^{6}$ Faculty of Medicine. University of Kelaniya. Ragama. Sri Lanka. ${ }^{7}$ Unité de Génétique Clinique, Hôpital Robert Debré. Paris. France.

Hartsfield syndrome

Corresponding author: Catheline Vilain. Service de Génétique Médicale. ULB. Hôpital Erasme. 808 route de Lennik. 1070 Brussels. Belgium.

Phone: 32255564 30. fax: 32255564 40. e-mail: cavilain@ulb.ac.be 


\begin{abstract}
.
We report on five male subjects with a triad of signs compatible with Hartsfield syndrome: ectrodactyly, holoprosencephaly, and mental retardation. Only 6 patients with this distinctive association have been reported over the past 20 years, all of them being males. Of the patients described here, some have unreported findings such as vermian hypoplasia in one and prolonged survival into adulthood in two. Two patients developed central diabetes insipidus. All were mentally retarded. No abnormalties were found at the cytogenetic level, including array CGH in two. No known genes for holoprosencephaly or ectrodactyly were found, including GLI2. The cause of Hartsfield syndrome is unknown. An X-linked defect is possible, although no recurrences have been described to date. Our observations almost double the number of cases. They underscore the usefulness of fetal brain imaging in the differential diagnosis of syndromal clefting diagnosed in utero, particularly when ectrodactyly-ectodermal dysplasia-clefting syndrome is suspected.
\end{abstract}

KEYWORDS: holoprosencephaly,ectrodactyly,hypertelorism, vermian hypoplasia, GLI2 
3.

\section{INTRODUCTION}

The association of holoprosencephaly, ectrodactyly, cleft lip and palate, and hypertelorism was first reported by Hartsfield [1984]. To date, 5 additional patients, all males, have been added [Young 1992; Imaizumi, 1998; Corona-Rivera, 2000; Abdel-Meguid, 2001; Konïg, 2003]. Cleft lip-palate, and hypertelorism were not constant features. In some patients endocrine dysfunction was present: hypernatremia in three [ Imaizumi, 1998; Abdel-Meguid, 2001; Konïg ,2003] and hypogonadotropic hypogonadism in one [Konïg, 2003]. Surviving patients were severely mentally retarded. The condition was sporadic in all cases. Except for one patient with a de novo apparently balanced $\mathrm{t}(2 ; 4)(\mathrm{q} 14.2 ; \mathrm{q} 35)$ translocation, no abnormalies were identified at the cytogenetic or molecular level. We report on 5 additional patients, 3 with prolonged survival, 1 with an unreported central nervous system abnormality and with severe manifestations.

\section{CASE REPORTS}

Patent 1. The proband was the third child of a healthy unrelated couple of Northern African origin. Family history was unremarkable. At 24 weeks of gestation, ectrodactyly and cleft lip were noted by ultrasonography, suggesting ectrodactyly-ectodermal dysplasia-clefting (EEC) syndrome. At 32 weeks of gestation, a brain MRI disclosed vermian hypoplasia. Termination of pregnancy was decided at 36 weeks. Post-mortem examination showed a male fetus of $2480 \mathrm{~g}\left(50^{\text {th }}\right.$ centile $)$, with a length of $46 \mathrm{~cm}\left(25^{\text {th }}\right.$ centile) and a head circumference of $32 \mathrm{~cm}\left(50^{\text {th }}\right.$ centile $)$. A left labial and gingival cleft; mild hypertelorism; flat nasal tip; and malformed, flat, and angulated right ear were also observed. Both hands had 5 digits, the $3^{\text {rd }}$ being hypoplastic with an absent nail. There was syndactyly between 3rd and 4th digits and a wide gap between 2nd and 3rd fingers. Radiographic examination demonstrated absence 
of the distal phalanx of both $3^{\text {rd }}$ digits and normal metacarpal bones. The feet had ectrodactyly with only 3 toes. The halluces were broad, with hypoplastic nails; they were widely separated from the two others digits. The genitalia were normal. There were no visceral abnormalities. The skin showed no abnormality, but signs of mild hyperkeratosis were present on histological examination. Global vermian hypoplasia, and absence of olfactory bulbs were observed at autopsy. The cerebellar hemispheres were of normal size and widely spaced. Histological examination showed abundant vermian neuronal heterotopia.

Patient 2. This boy had previously been reported at 2 years of age as an example of EEC with vasopressin and gonadotropin deficiency [Van Maldergem, 1992]. He was the first son of unrelated Belgian healthy parents aged 22 and 27 years at the time of birth. He has an unaffected younger brother. The family history was unremarkable. Pregnancy was complicated by non-A, non-B hepatitis. Delivery was at term. Birth weight was $3.350 \mathrm{~g}$; length was $51 \mathrm{~cm}$; and head circumference was $31.5 \mathrm{~cm}$. Apart from microcephaly, he had multiple congenital anomalies including ectrodactyly of both hands with absence of the $2^{\text {nd }}$ digit, hypoplastic $3^{\text {rd }}$ digit and fused $2^{\text {nd }}$ and $3^{\text {rd }}$ metacarpal bones, as well as ectrodactyly of feet. Bilateral cleft lip and palate, telecanthus, and a poorly lobulated left ear were also noted. He had bilateral cryptorchidism and a micropenis. Scalp hair was sparse but normal when examined microscopically between polarizing filters, and there were no other signs of ectodermal dysplasia. At 3 months of age, hypernatremia was observed. Polyuria and low urinary osmolarity were documented. Intranasal desmopressin test increased urinary osmolarity from 142 to $590 \mathrm{mosm} / \mathrm{kg}$, leading to the diagnosis of central diabetes insipidus. Hypodypsia was later documented as well. Gonadotrophin deficiency was the only antehypophyseal defect. Brain MRI disclosed lobar holoprosencephaly and partial agenesis of the corpus callosum. The normal posterior pituitary hyperintense signal was absent in infancy, although it was present on the last MRI performed. At 19 years of age, patient 2 has moderate to severe mental retardation. He has never been able to walk, and is wheelchairbound because of spastic 
paraplegia. He has truncal hypotonia with mild scoliosis. Height is evaluated to $160 \mathrm{~cm}$, well below the target hight of $176.5+/-8.5 \mathrm{~cm}$. He has acquired good verbal skills, but is not able to read or write.

Despite treatment of central diabetes insipidus and hypodipsia, the patient has a propensity for hypertonic dehydratation and episodes of hypernatremia. Hypogonadotropic hypogonadism is present. Puberty was induced by incremental doses in testosterone ester (Sustanon $\left.{ }^{\circledR}\right)$ from the age of 13,3 years, but stopped at stage Tanner 3, with penile length of $6 \mathrm{~cm}$, and small testes $(3 \mathrm{ml})$, despite adult testosterone dosages. Anosmia is suspected. He has no sign of ectodermal dysplasia, hair, skin and shape of teeth being normal. Patent 3: The patient is the first child of first cousins, healthy Sri Lankan parents, the mother aged 24 years and the father aged 25 years. Family history is unremarkable except for one maternal aunt reported as having a cleft lip and palate. Pregnancy was uncomplicated. The mother denied teratogen exposure and there was no history of infection during the pregnancy. The parents had been informed at 15 weeks of gestation that the prenatal ultrasound showed anomalies. However, termination of pregnancy because of fetal anomalies is not a legal option in Sri Lanka. Delivery was at term. Birth weight was $3.400 \mathrm{~g}$, length was $50.4 \mathrm{~cm}$, and head circumference was $41.8 \mathrm{~cm}$. The patient had multiple congenital anomalies. There was macrocephaly, with prominent metopic and coronal sutures and a widely patent sagittal and lambdoid sutures and anterior and posterior fontanelles. Premaxillary agenesis with a large median cleft in upper lip and palate was noticed. There was hypotelorism with an inner canthal distance of $1.8 \mathrm{~cm}$ (well below $3^{\text {rd }}$ centile). Ears were small, simple, rounded, low-set, and posteriorly angulated. All four limbs showed ectrodactyly, with the hands having two digits and the feet only one digit each. Holoprosencephaly was confirmed on CT scan, showing minimal cortical development of the frontal, parietal and temporal lobes, fused thalami, absence of the corpus callosum and falx cerebri, a single ventricle, and normal cerebellum. Patient 4: The patient is the first son of unrelated Caucasian parents who were both 21 years old at the time of birth. The father had juvenile diabetes since the age of 14 years. Family history is otherwise unremarkable. The patient has an unaffected paternal half-brother, and a healthy maternal half sister. Pregnancy was uncomplicated and spontaneous vaginal delivery occurred at 40 weeks. At birth, weight 
was $3120 \mathrm{~g}$, length was $50 \mathrm{~cm}$, and head circumference was $34 \mathrm{~cm}$. Bilateral ectrodactyly of the hands was noted, with all fingers being present. Feet were abnormal with only three digits on the left foot, and four digits on the right foot, with syndactyly. At 7 months of age, a plasma sodium of $172 \mathrm{mEq} / \mathrm{L}$ was found. The diagnosis of central diabetes insipidus was made, based on the presence of severe hypernatremia, a urine density of $1003 \mathrm{mosm} / \mathrm{kg}$, and a positive response to desmopressin. The penis was noted to be small. A computerized tomographic scan disclosed lobar holoprosencephaly and partial hypoplasia of the corpus callosum. At 6 year 8 months, the IQ was evaluated at 63 (Stanford-Binet score). At 7 years 6 months, bilateral orchidopexy was performed. At 13 years, the mother reported that her son never felt thirsty, even when polyuric and hypernatremic. At age 14 years 8 months, hypogonadotropic hypogonadism was confirmed (pubertal stage Tanner G1P1, testicular volume 1 to $2 \mathrm{ml}$, LHRH test: LH 1.7 to $2.3 \mathrm{mIU} / \mathrm{L}, \mathrm{FSH}<1.8$ to $2.7 \mathrm{mIU} / \mathrm{L}$ ). Pubertal induction with testosterone enanthate was started, and puberty reached stage Tanner P5G5 (except for $2 \mathrm{ml}$ testes). On magnetic resonance imaging at the age of 15 years, the hyperintense signal of the posterior pituitary was normal. Adult height is $161.6 \mathrm{~cm}$, below the sex-adjusted target height of $172.5 \pm 8.5 \mathrm{~cm}$, in spite of normal GH secretion. At 29 years of age, the patient still lives with his mother and stepfather and works in a sheltered workshop.

Patient 5: The male proband is the second child of young, non-consanguineous parents. An older sister and younger brother are healthy. The mother was born with a unilateral cleft lip. The boy was delivered at 42 weeks of gestation with a birth weight of $3730 \mathrm{~g}$, length of $51 \mathrm{~cm}$ and head circumference of $35 \mathrm{~cm}$. After birth multiple congenital anomalies affecting the limbs and craniofacial region were found. In the face, a preauricular tag on the left side and bilateral cleft lip and palate were noted. Both hands were abnormal with bifurcation of the thumbs, absent second fingers, absent (right side) or dysplastic (left side) third fingers, abnormal fourth fingers with broad basis and camptodactyly (left side) and clinodactyly of fifth fingers. Both feet showed ectrodactyly with equinovarus deformity. The external genitalia were small. Because of this constellation of findings, initially the diagnosis of EEC syndrome was made. However this diagnosis was subsequently considered unlikely when a MRI scan of the brain disclosed 
semilobar holoprosencephaly. The boy developed severe failure to thrive with slow staturoponderal and psychomotor development. All physical parameters (weight, length and head circumference) at the age of 6 years were between 3 to 3.6 standard deviations below the mean. At the age of 12 years he is still not able to speak or walk. He sits in a wheelchair and has a developmental age of about 7 months. He had surgery at the age of 4 and 11 years because of left hip dysplasia.

\section{CYTOGENETIC AND MOLECULAR INVESTIGATIONS}

Several cytogenetic and molecular analysis were carried on these patients with family consent. All cases had a normal karyotype. Array CGH (1 Mb BAC array)[ Menten, 2006] was performed in patient 5, and high resolution oligonucleotide CGH-arrays (41k pannucleotide arrays, Agilent ${ }^{\circledR}$ ) was performed in patient 3 which did not disclose evidence for the presence of small chromosomal imbalances. In patient 1 , we did not find any mutations in three HPE genes (SHH, ZIC2, and SIX3 genes) using dHPLC, and the possibility of a deletion/duplication anomaly was excluded in the TGIF, SHH, ZIC2, SIX3 genes by Quantitative Multiplex PCR of Short Fluorescent fragments. On sequencing of coding sequences and splice sites of the P63 gene, no mutations were found in patients 1 (S. Manouvrier-Hanu. Lille. France), 2, 4 and 5 (H. Scheffer, Nijmegen, the Netherlands). We studied the coding sequence and intron-exon boundaries of GLI2 in all patients, but detected only known polymorphisms.

\section{DISCUSSION}

The five patients reported here have Hartsfield syndrome (OMIM 300571). Table I summarizes their findings and those of 6 previously reported cases. These 11 patients illustrate the variable expression of this condition. Because holoprosencephaly and ectrodactyly are the only constant findings, they should be considered hallmarks of the syndrome. In previously described cases, holoprosencephaly was either lobar or semilobar. Additional brain anomalies included arhinencephaly (2 patients)[Hartsfield, 1984; Young, 1992], hypoplastic or incomplete corpus callosum (3 cases) [Hartsfield, 1984; Imaizumi, 1998; CoronaRivera, 2000], absent septum pellucidum (3 cases) Imaizumi, 1998; Corona-Rivera, 2000; Abdel-Meguid 2001], all being part of the holoprosencephalic spectrum. Pachygyria was reported in one patient 
[Corona-Rivera, 2000]. Patient 1 in the present report had arhinencephaly, a mild expression of the holoposencephaly. He also had vermian hypoplasia which had not previously been reported. The four other patients had semilobar or lobar holoprosencephaly and hypoplasia or agenesis of the corpus callosum.

Ectrodactyly, the second constant finding of the syndrome, is also variable in its expression. Patient 3 displayed the most severe example of ectrodactyly, with only two digits on both hands, and one digit on both feet. Patient 5 had duplicated thumbs. The patient described by Young et al. [1992] had polysyndactyly. The patient described by Hartsfield et al. [1984] had absent right radius.

Cleft lip and palate are variable findings. Bilateral cleft lip and palate is the most frequent finding (5/11). This differs from premaxillary agenesis with median cleft lip usually observed in the holoprosencephaly. Clefting is absent in patient 4, and in two other previously described patients [Corona-Rivera, 2000; Abdel-Meguid, 2001]. Patient 1 had mild unilateral labial and gingival clefting.

Hypertelorism, an inconstant feature of the syndrome, has been reported on occasion [Cohen, 2006]. Five of the 11 reported cases had hypertelorism, while three had hypotelorism.

Patient 2 and 4 have hypodipsic hypernatremia associated with central diabetes insipidus. Hypernatremia was also present in three previously reported patients [Imaizumi, 1998; Abdel-Meguid ,2001; Konïg 2003]. In the patient described by König et al.[2003], hypernatremia was diagnosed at the age of 18 months; he had attenuated antidiuretic hormone release despite high plasma osmolality levels. This observation was presumed to be due to a re-setting of the threshold sensitivity of the osmoreceptors in the CNS. In the patient described by Imaizumi et al. [1998], diabetes insipidus was diagnosed at the age of 6 months and not further described. Hypogonadotrophic hypogonadism was reported in the patient 
described by Konïg et al. [2003] and was documented in patients 2 and 4. Although most patients were reported to be short, growth hormone deficiency was only reported in one case [Konïg 2003]. Hypothalamic-pituitary dysfunction is known to occur in holoprosencephaly, with or without absent or hypoplastic pituitary. [Cohen, 1989; Cameron, 1999; Cuisset, 1999]

Because of the association of ectrodactyly and orofacial clefting, EEC syndrome was suspected in at least three of the five patients described in this report, but this diagnosis was challenged after the discovery of midline brain anomalies reminiscent of holoprosencephaly. Brain anomalies have rarely been described in patients with EEC syndrome. Except for patients with Hartsfield holoprosencephaly-ectrodactyly syndrome, only anecdotal reports of the association of ectrodactyly, clefting, and brain malformations have beendescribed (vermian hypoplasia and Dandy Walker cyst [Atkin ,1984], agenesis of the corpus callosum [Ronconi, 1985], and isolated absent septum pellucidum [Knudtzon, 1987].

Only one patient had two healthy maternal half brothers. [Corona-Rivera, 2000]. Patients 2, and 5 have unaffected maternal brothers. Family history is reported to be unremarkable in most cases, except for the patient described by Hartsfield, who had distant relatives with ectrodactyly; patient 5 whose mother had unilateral cleft lip; and patient 3 whose maternal aunt had cleft lip-palate.

. All patients including our cases had a normal karyotype, except one patient with a de novo apparently balanced translocation $\mathrm{t}(2 ; 4)(\mathrm{q} 14.2 ; \mathrm{q} 35)$. Because GLI2 maps to $2 \mathrm{q} 14.2$, which is close to one of the breakpoints, we studied the patient, but no pathogenic GLI2 mutations were identified. Testing for some genes known to cause holoprosencephaly $(S H H, Z I C 2$, and $S I X 3)$ produced negative results. 
Our observations bring to eleven the number of patients with holoprosencephaly and ectrodactyly (Hartsfield syndrome). They highlight the variable expression of the syndrome. The etiology of Hartsfield syndrome remains unknown. All reported patients have been male. There is a $0.9610^{-3}$ probability for eleven patients to share the same sex, and a $0.4810^{-3}$ probability for them to be all males. In the absence of gene known to be responsible for the syndrome, it is tempting to speculate on a multifactorial origin with some major gene on the $\mathrm{X}$ chromosome to account for the absence of female patients and of intrafamilial recurrence.

\section{ACKNOWLEDGMENTS}

We thank Marc Abramowicz for a critical reading of our manuscript. We thank Julie Désir for constructive discussion about candidate genes. We thank Lionel Van Maldergem for his comment on the phenotype of case 2. We thank Françoise Menez, Anne-Lise Delezoide, and Catherine Garel for their advice on case 1 . 


\section{REFERENCES}

Abdel-Meguid N, Ashour M. 2001. Holoprosencephaly and split hand/foot: an additional case with rare association. Clin Dysmorphol 10:277-279.

Atkin J, Patil S. 1984. Apprently new oculo-cerebro-acral syndrome. Am J Med Genet 19:585-587.

Cameron FJ, Khadilkar VV, Stanhope R. 1999. Pituitary dysfunction, morbidity and mortality with congenital midline malformation of the cerebrum. Eur J Pediatr. 158:97-102.

Cohen MM. 1989. Perspective on Holoprosencephaly:Part III. Spectra, distinctions, continuities, and discontinuities. Am J Med Genet. 34:271-288.

Cohen M Michael Jr. 2006.Holoprosencephaly: Clinical, anatomic, and molecular dimensions. Birth Defect Research. (Part A) 76:658-673.

Corona-Rivera A, Corona-Rivera R, Bobadilla-Morales L, Garcia-Cobian T, Corona-Rivera E. 2000. Holoprosencephaly, hypertelorism, and ectrodactyly in a boy with apparently balanced de novo $\mathrm{t}(2 ; 4)(\mathrm{q} 14.2 ; \mathrm{q} 35)$.Am J Med Genet 90:423-426.

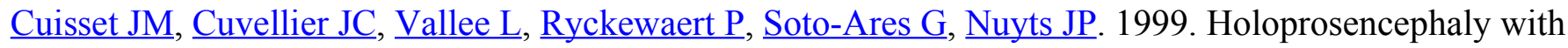
neurogenic hypernatremia. Arch Pediatr. 6(1):43-5. 
Hartsfield J, Bixler D, DeMeyer W. 1984. Hypertelorism associated with holoprosencephaly and ectrodactyly. The Journal of Clinical Dysmorphology. 2:27-31.

Imaizumi K, Ishii T, Masumo M, Kuroki Y. 1998. Association of holoprosencephaly, ectrodactyly, cleft lip/palate and hypertelorism : a possible third case. Clin Dysmorphol. 7:213-216.

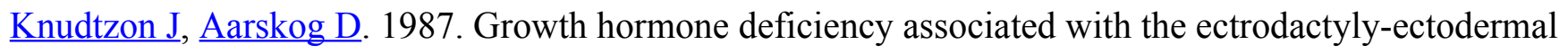
dysplasia-clefting syndrome and isolated absent septum pellucidum. Pediatrics. 79:410-412.

Konïg R, Beeg T, Tariverdian G, Scheffer H, Bitter K. 2003. Holoprosencephaly, bilateral cleft lip and palate and ectrodactyly: Another case and follow up. Clin Dysmorphol. 12:221-225.

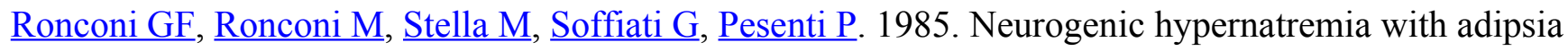
and cerebral malformations in a child with ectrodactyly-ectodermal dysplasia-cleft lip-palate syndrome. Pediatr Med Chir. 7:893-897.

.Van Maldergem L, Gillerot Y, Vamos E, Toppet M, Watillon P, Van Vliet G. 1992.Vasopressin and gonadotrophin deficiency in a boy with the ectrodactyly-ectodermal dysplasia-clefting syndrome. Acta paediatric. $81: 365-367$.

Young I, Zuccollo J, Barrow M, Fowlie A. 1992.Holoprosencephaly, tetecanthus and ectrodactyly: a second case. Clin Dysmorphol. 1: 47-51. 


\section{LEGENDS}

Table I. Comparision of clinical data of the 6 previously reported cases [Hartsfield, 1984; Young, 1992; Imaizumi, 1998; Corona-Rivera, 2000; Abdel-Meguid, 2001; Konïg 2003] and of the patients 1 to 5, highlighting clinical variability in the expression of the Harstfield syndrome.

Abbreviations : M, male; nl, normal ; ex, exon.

Fig 1. Photographs of faces (frontal and lateral views), hands and feet of patients 1-5, showing variable clefting, and variable expression of ectrodactyly. 